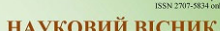

Sientific messenger of Lviv National University

$\longrightarrow$

(11)

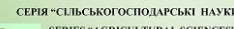

Том 22 № 93

2020

Науковий вісник Дьвівського національного університету ветеринарної медицини та біотехнодогій імені С.3. Гжицького. Серія: Сільськогосподарські науки

Scientific Messenger of Lviv National University of Veterinary Medicine and Biotechnologies. Series: Agricultural sciences

UDC 636.2.636.082

\title{
Evaluation of highly productive cows by selection and genetic parameters
}

\author{
T. V. Pidpala, Yu. S. Matashnyuk \\ Mykolayiv National Agrarian University, Mykolayiv, Ukraine
}

\section{Article info}

Received 10.08.2020

Received in revised form 09.09 .2020

Accepted 10.09.2020

Mykolayiv National Agrarian University

Georgiya Gongadze Str., 9 Mykolayiv, 54020, Ukraine Tel.: +38-099-502-69-82

E-mail:yuramatash@gmail.com
Pidpala, T. V., \& Matashnyuk, Yu. S. (2020). Evaluation of highly productive cows by selection and genetic parameters. Scientific Messenger of Lviv National University of Veterinary Medicine and Biotechnologies. Series: Agricultural sciences, 22(93), 22-28. doi: 10.32718/nvlvet-a9304

Under the conditions of intensive technologies used in production of livestock products, the main selection feature that characterizes the economic feasibility of dairy farming and breeding value of animals is milk productivity. One of the factors that affects, not only the economy of production, but also the improvement of herds and breeds of cattle, is the use of highly productive cows. Therefore, the aim of our research was to assess the level of development of productive traits in Holstein cows under the conditions of intensive milk production technology, according to selection and genetic parameters. To conduct the study, a group of 1089 first-born cows was formed with the help of the Dairy Comp program and Microsoft Excel. The material for the research was the milk productivity of Holstein cows during the first three lactations. The level of development of selection traits in animals was determined by selection and genetic parameters. It was found that from the sample $n=1089$ to the group of highly productive animals (">10560") were included 266 cows, and low-productive animals (" $<8706 ")-249$ first-borns. They had an average milk yield for the first lactation, $11439 \mathrm{~kg}$ of milk with a fat content of $3.96 \%$ and $7737 \mathrm{~kg}$ of milk and $3.95 \%$, respectively. There is a difference in milk yield, milk fat and protein between the groups of cows " $>10614$ " and " $<8706$ ", but there is a general tendency towards changes in productivity with age. Based on the data of milk recurrence and the amount of milk fat of high-yielding cows (group ">10614"), it was found that higher values of the coefficient are characteristic of lactations I-III $\left(r_{w}=0.105 ; r_{w}=0.135\right)$. As a result of comparative analysis it was found that low-yielding animals (group " $<8706$ ") were characterized by higher recurrence rates for I-II and I-III lactation $\left(r_{w}=0.345 ; r_{w}=0.316 ; r_{w}=0.320\right.$ and $r_{w}=0.664 ; r_{w}=$ $0.646 ; r_{w}=0.651$, respectively). Higher rates of recurrence of traits of milk productivity are the characteristic of low-yielding cows (group " $<8706$ "), i.e. they had more consistency of traits during different lactations and animals with a high level of productivity did not differ in age constancy. At a high level of milk yield in cows of group "> 10614" appeared a negative correlation of low and medium level $(r=-0.423)$. It was also found a negative correlation of low and medium level between milk yield and protein content in milk $(r=-0.007 \ldots-0.332)$. At lower milk yields, there is no negative correlation between milk yield and fat content in milk. Thus, the existence of a negative correlation between milk yield and fat content in milk at a high level of animal productivity, and between milk yield and protein content in milk at both high and low levels of cow productivity was proved.

Key words: Holstein breed, highly productive cows, milk productivity, trait, variability, correlation, recurrence.

\section{Оцінка високопродуктивних корів за селекційно-генетичними параметрами}

\author{
Т. В. Підпала, Ю. С. Маташнюк
}

Миколаївський національний аграрний університет, м. Миколаїв, Украӥна

В умовах інтенсивних технологій виробництва продукиї скотарства основною селекційною ознакою, щцо характеризує економічну дочільність розведення молочної худоби і племінну иінність тварин, є молочна продуктивність. Один із факторів, цио впливає не лише на економіку виробництва, а й на удосконалення стад і порід великої рогатої худоби - використання високопродуктивних корів. Тому метою наших досліджень було оцінити за селекційно-генетичними параметрами рівень розвитку продуктивних 
ознак у корів голитинської породи в умовах інтенсивної технології виробництва молока. Для проведення дослідження було сформовано за допомогою програми Dairy Cотр та Microsoft Excel групу з корів-первісток у кількості 1089 голів. Матеріалом для дослідження були дані молочної продуктивності корів голитинської породи за перші три лактаиії. Рівень розвитку селекиійних ознак у тварин визначали за селекиійно-генетичними параметрами. Встановлено, що із вибіркової сукупності $n=1089$ до групи високопродуктивних тварин ("> 10560") ввійтло 266 корів, а до низькопродуктивних ("<8706”) - 249 первісток. Вони мали середній надій за периу лактацію 11439 кг молока з вмістом жиру 3,96 \% і 7737 кг молока та 3,95 \% відповідно. Різниия за величиною надою, кількістю молочного жиру $і$ білка між групами корів “>10614” $i$ “<8706” існує, проте спостерігається загальна тенденція щодо зміни продуктивності з віком тварин. На підставі даних повторюваності надою і кількості молочного жиру високопродуктивних корів (група “>10614”) встановили, щчо більші значення коефіцієнта характерні для лактацій I-III ( $r_{w}=0,105$; $\left.r_{w}=0,135\right)$. У результаті порівняльного аналізу встановлено, щчо низькопродуктивні тварин (група “<8706”) характеризувалися вищими коефіцієнтами повторюваності за I-II і II-III лактації $\left(r_{w}=0,345 ; r_{w}=0,316 ; r_{w}=0,320\right.$ i $r_{w}=0,664 ; r_{w}=0,646 ; r_{w}=0,651$ відповідно). Вищі показники повторюваності ознак молочної продуктивності характерні для низькопродуктивних корів (група “<8706”), тобто вони мали більшу постійність ознак за різні лактації, а тварини з високим рівнем продуктивності не відрізнялися віковою постійністю. За високого рівня надою у корів групи “>10614” появилася від'ємна корелячія низького $i$ середнього ступеня $(r=-0,423)$. Також виявлено від’ємну кореляиію низького і середнього ступеня між надоєм $і$ вмістом білка в молоиі $(r=-0,007 . .$. -0,332). За меншого рівня надою від 'ємна корелячія між надоєм і вмістом жиру в молочі не проявляється. Таким чином, доведено існування від'ємної корелячії між надоєм і вмістом жиру в молочі за високого рівня продуктивності тварин, а між надоєм та вмістом білка в молоці як за високого, так і низького рівня продуктивності корів.

Ключові слова: голштинська порода, високопродуктивні корови, молочна продуктивність, ознака, мінливість, кореляція, повторюваність.

\section{Вступ}

В умовах інтенсивних технологій виробництва продукції скотарства основною селекційною ознакою, що характеризує економічну доцільність розведення молочної худоби і племінну цінність тварин, є молочна продуктивність. При цьому набуває значення використання спеціалізованих молочних порід великої рогатої худоби, серед яких найбільш пристосована до промислових технологій - голштинська порода. Середній надій корів у стадах коливається в межах 8000 10000 кг молока 3 масовою часткою жиру 3,5...3,6 \% жиру (Morozova et al., 2012). У племінному заводі голштинської породи СТОВ “Промінь” Арбузинського району Миколаївської області надій на одну корову за 2016 рік становив 10722 кг (Pidpala et al., 2018), а за 2018 році - 11069 кг (Pidpala et al., 2019). В умовах ТОВ "Українська молочна компанія" надій корів голштинської породи за першу лактацію становив 8934 кг, другу - 9750, третю - 9540 кг молока (Koropets et al., 2016), є сільськогосподарські підприємства, де з розрахунку на дійну корову середня продуктивність корів перевищує 12000 кг за рік (Livinskyi, 2014). Повідомляється, що світовий рекордний надій корови № 1326 голштинської породи за 365 днів третьої лактації становив 32804 кг молока 3 вмістом жиру 3,86 \% і білка 3,12 \% (Morozova et al., 2012).

Одним із факторів, що впливає не лише на економіку виробництва, а й на удосконалення стад і порід великої рогатої худоби, є використання високопродуктивних корів та їхнє довголіття (Babik et al., 2017; Babik, 2018). Повідомляється, що доцільність подальшого використання тієї чи іншої групи корів у стаді має визначати не їхній вік, а показники продуктивності корів порівняно із середньою продуктивністю стада (Shkurko, 2014). Попередніми нашими дослідженнями встановлено, що в корів, які за першу лактацію проявили високий рівень продуктивності, й у наступні лактації надій збільшувався. Вищі коефіцієнти повторюваності $\left(r_{w}=0,436, r_{w}=0,378\right)$ характеризували вікову постійність ознак надою і кількості молочного білка (Pidpala \& Matashniuk, 2019). Було також з'ясовано, що високими та достовірними є коефіцієнти повторюваності за оцінкою першої та другої лактації (Khmelnychyi \& Loboda, 2015), встановлено високі оцінки кореляції між оцінками жирномолочності в різні місяці лактації (Kramarenko et al., 2019).

В селекції молочної худоби для досягнення бажаного рівня розвитку продуктивності необхідно врахувати корелятивні зв'язків між ознаками, зміну величини й характеру цих зв'язків у суміжних поколіннях (Pidpala et al., 2012). У більшості корів-дочок бугаївплідників голштинської породи виявлено від'ємну кореляцію між величино надою і вмістом жиру в молоці $(r=-0,09 \ldots-0,57)$, додатну - між вмістом жиру і білка $(r=0,56 \ldots 0,78)$, між надоєм і кількістю молочного жиру та білка $(r=0,86 \ldots 0,99)$ (Ferents, 2017; Pidpala et al., 2019).

Поряд з природно існуючими зв'язками між продуктивними ознаками в процесі селекції виникають нові, які можуть бути додатними і від'ємними, оскільки їх фенотипічний прояв є взаємною дією спадкових і середовищних факторів (Kramarenko et al., 2018). Дослідженнями вчених (Pidpala et al., 2012) встановлено, що в результаті тривалої однобічної селекції червоної степової породи за жирномолочністю відбулася зміна слабкої від'ємної кореляції ( $r=-0,140$, $\mid \mathrm{P}>0,95)$ між надоєм і вмістом жиру в молоці до слабкої додатної $(r=+0,060, \mathrm{P}<0,95)$. Здійснення селекції на підвищення молочності з використанням генофонду голштинської породи зумовило перебудову кореляційних зв'язків між надоєм і вмістом жиру в молоці $(r=-0,444, \mathrm{P}>0,999)$. Виявлені зв'язки можна використовувати в селекції для прискорення процесу удосконалення молочних порід худоби.

Незалежно від інтенсифікації галузі завжди були і залишаються пріоритетними селекційними ознаками показники молочної продуктивності корів. Підвищення продуктивності молочної худоби значною мірою залежить від використання корів 3 високою продуктивністю. Тому дослідження селекційно-генетичних параметрів високопродуктивних тварин $є$ актуальним.

Мета досліджень. Оцінювання за селекційногенетичними параметрами рівня розвитку продуктивних ознак у корів голштинської породи в умовах інте- 
нсивної технології виробництва молока. Досягнення зазначеної мети здійснювалося шляхом виконання таких завдань: визначити середній рівень продуктивності корів вибіркової сукупності, розподілити за рівнем надою на три групи, оцінити ступінь повторюваності, кореляційний зв'язок між ознаками у високопродуктивних корів голштинської породи.

\section{Матеріал і методи досліджень}

За інтенсивної технології виробництва молока досліджували мінливість ознак у високопродуктивних корів в умовах племзаводу СТОВ “Промінь" Арбузинського району Миколаївської області. Господарство є одним 3 лідерів серед виробників молока. Завдяки впровадженим технологічним рішенням середній надій на одну корову в 2019 році становив 11906 кг молока. Характеристика інтенсивної технології та потоково-цехової організації виробництва висвітлена у попередніх дослідження (Pidpala \& Matashniuk, 2017).

Для проведення дослідження було сформовано за допомогою програми Dairy Comp та Microsoft Excel групу з корів-первісток у кількості 1089 голів. Піддослідні тварини за віком належать до дочірнього покоління порівняно з коровами у попередніх дослідженнях (Pidpala \& Matashniuk, 2019). Матеріалом для дослідження були дані молочної продуктивності корів голштинської породи за перші три лактації.

Рівень розвитку селекційних ознак у тварин визначали за селекційно-генетичними параметрами: середньою арифметичною величиною $(\bar{X})$, їі похибкою $(S x)$, середнім квадратичним відхиленням $(\sigma)$, коефіцієнтом варіації $\left(C_{v}\right)$, коефіцієнтом повторюваності $\left(r_{w}\right)$, коефіцієнтом кореляції $(r)$, використовуючи статистичні методи (Kramarenko et al., 2019).

Для встановлення закономірностей співвідносної мінливості між селекційними ознаками у високопродуктивних корів дочірнього покоління визначали помилку і вірогідність вибіркового коефіцієнта кореляції (Pidpala et al., 2012).

$$
r=\frac{\sum x y-\left(\sum x \cdot \sum y\right) \div n}{\sqrt{C x \cdot C y}},
$$

де: $x$ - значення варіанту першої та другої ознаки; $y$ - значення варіанту першої та другої ознаки; $C x-$ дисперсія за першою (х) ознакою; $C y$ - дисперсія за другою (у) ознакою.

Для встановлення відповідності розподілу тварин на три групи із закономірностями нормального розподілу використовували метод $\chi^{2}$ (хі-квадрат) (Pidpala et al., 2012).

\section{Результати та їх обговорення}

Для розподілення досліджуваних тварин на групи за рівнем надою і виявлення серед них високопродуктивних корів визначили прояв селекційних ознак за першу лактацію (табл. 1). Із вибіркової сукупності (n = 1089) згідно з відхиленням $\bar{X} \pm 0,67 \sigma$ сформували три групи тварин відповідно до рівня їхнього надою.

\section{Таблиця 1}

Характеристика молочної продуктивності корів-первісток голштинської породи (дочірнє покоління), n = 1089

\begin{tabular}{lcccc}
\hline \multicolumn{1}{c}{ Ознака } & \multicolumn{3}{c}{ Параметр } \\
\cline { 2 - 5 } & $\bar{X}$ & $S x$ & $\sigma$ & $C \nu, \%$ \\
\hline Надій, кг & 9660 & 43,13 & 1423,40 & 14,7 \\
Вміст жиру в молоці, \% & 3,96 & 0,005 & 0,173 & 4,4 \\
Вміст білка в молоці, \% & 3,26 & 0,003 & 0,086 & 2,6 \\
Кількість молочного жиру, кг & 382,1 & 1,79 & 59,10 & 15,5 \\
Кількість молочного білка, кг & 315,3 & 1,43 & 47,16 & 15,0 \\
\hline
\end{tabular}

Оскільки продуктивність всіх первісток становила 9660 кг молока, то до низькопродуктивних належали тварини, надій яких, з урахуванням $\bar{X}-0,67 \sigma$, становив 8706 кг молока і менше (група “<8706” - низькопродуктивні, $\mathrm{n}=249)$; первістки 3 надоєм в межах від 8707 до $10613(\bar{X} \pm 0,67 \sigma)$ склали групу з середнім рівнем (“8707-10613" - середньопродуктивні, $\mathrm{n}=574$ ) i всі корови, які мали надій за першу лактацію 10614 кг молока і вище $(\bar{X}+0,67 \sigma)$ ввійшли до групи ">10560" - високопродуктивні тварини $(\mathrm{n}=266)$.

Визначене співвідношення корів в групах, як 1:2:1 узгоджується із закономірностями нормального розподілу (Ю. А. Філіпченко, цитується за (Pidpala et al., 2012)), оскільки $\chi^{2}=3,726$ і нижче граничних табличних значень $\left(\chi^{2}\right.$ таб. $=6,0-9,2-13,8$ при $\left.v=2\right)$. Розрахована величина $\chi^{2}$ порівняно 3 табличним значенням 3 урахуванням ступенів свободи $v$ невірогідна $(\mathrm{P}<0,05)$. Отже, різниця між фактичним і теоретич- ним розподілом на групи невірогідна і встановлений розподіл тварин можна вважати таким, який відповідає нормальному розподілу.

У результаті порівняльного аналізу прояву ознак високопродуктивними коровами (група ">10614") i ровесницями 3 рівнем надою 8706 і нижче (група “<8706”) встановлено, що інтенсивне продукування зумовлює швидше вибуття тварин зі стада. Так, після першої, другої та третьої лактацій поголів'я високопродуктивних корів зменшилося на 15,7 \%; 54,5 \% та $86,9 \%$, тимчасом як в групі “<8706” - на 20,0\%; $36,6 \%$ і 64,0 \% відповідно. За рівнем продуктивності перевагу мали тварини групи “>10614” (табл. 2). За першу лактацію їхній надій був вищим на 1908 кг ( $>0,001)$ молока, ніж у первісток групи “<8706". Аналогічно перевагу встановлено й за другою і третьою лактаціями. Різниця становила 3702 кг $(\mathrm{P}<0,001), 1861$ кг $(\mathrm{P}<0,001)$. 
Таблиця 2

Характеристика високопродуктивних корів за молочною продуктивністю (дочірнє покоління), $\bar{X} \pm S x$

\begin{tabular}{|c|c|c|c|c|c|c|c|}
\hline \multirow{3}{*}{$\begin{array}{c}\text { Група корів } \\
\text { за рівнем } \\
\text { надою }\end{array}$} & \multirow{3}{*}{ Лактація } & \multirow{3}{*}{$\mathrm{n}$} & \multicolumn{5}{|c|}{ Ознака } \\
\hline & & & \multirow{2}{*}{ надій, кг } & \multicolumn{2}{|c|}{ молочний жир } & \multicolumn{2}{|c|}{ молочний білок } \\
\hline & & & & $\%$ & КГ & $\%$ & Кг \\
\hline \multirow{3}{*}{$>10614$} & I & 266 & $11439 \pm 39,7^{3}$ & $3,96 \pm 0,009$ & $453,2 \pm 1,94^{3}$ & $3,27 \pm 0,004$ & $373,6 \pm 1,39^{3}$ \\
\hline & II & 169 & $11882 \pm 151,1^{3}$ & $4,04 \pm 0,022$ & $480,3 \pm 6,72^{3}$ & $3,27 \pm 0,006$ & $388,7 \pm 5,00^{3}$ \\
\hline & III & 31 & $11438 \pm 364,7^{3}$ & $4,08 \pm 0,052$ & $464,1 \pm 14,0^{3}$ & $3,26 \pm 0,016$ & $372,6 \pm 11,6^{3}$ \\
\hline \multirow{3}{*}{$<8706$} & I & 249 & $7737 \pm 52,76$ & $3,95 \pm 0,011$ & $305,7 \pm 2,27$ & $3,27 \pm 0,005$ & $253,0 \pm 1,76$ \\
\hline & II & 146 & $10021 \pm 127,4$ & $3,99 \pm 0,022$ & $399,5 \pm 5,39$ & $3,28 \pm 0,006$ & $328,5 \pm 4,09$ \\
\hline & III & 48 & $9971 \pm 264,1$ & $4,02 \pm 0,038$ & $402,3 \pm 12,0$ & $3,26 \pm 0,013$ & $325,2 \pm 8,62$ \\
\hline
\end{tabular}

Примітка: ${ }^{1} \mathrm{P}<0,05 ;{ }^{2} \mathrm{P}<0,01 ;{ }^{3} \mathrm{P}<0,001$

Щодо кількості молочного жиру і молочного білка, то також вищим їх рівнем характеризувалися високопродуктивні корови. Встановлено, що різниця за кількістю молочного жиру в першій, другій, третій та четвертій лактаціях відповідно становила 147,5 кг $(\mathrm{P}<0,001), 80,8$ кг $(\mathrm{P}<0,001), 61,8$ кг $(\mathrm{P}<0,001)$.

За кількістю молочного білка також встановлені вірогідні різниці 120,6 кГ $(\mathrm{P}<0,001), \quad 60,2$ кГ $(\mathrm{P}<0,001), 47,4$ кг $(\mathrm{P}<0,001)$.

Варто зазначити, що різниця за величиною надою, кількістю молочного жиру і білка між групами корів “>10614” і “<8706” існує, проте спостерігається загальна тенденція щодо зміни продуктивності 3 віком тварин. Тобто, незалежно від рівня надою за першу лактацію з віком корів продуктивність їх збільшується, що $є$ біологічно закономірним і дана тенденція знайшла відображення в результатах наших досліджень.

Щодо корів, яких за рівнем продуктивності було віднесено до групи середньопродуктивних (“870710613”), то у них аналогічно проявляється дана закономірність. Їхній середній надій за першу лактацію становив 9669 кг молока з вмістом жиру 3,95 \% і білка 3,26 \%. Протягом наступних лактацій величина надою збільшилася і становила за II лактацію - 10933 кг, за третю - 10931 кг.

Порівняльним аналізом не встановлено відміннос- тей за вмістом жиру і білка в молоці між тваринами піддослідних груп. У корів групи “>10614” жирномолочність коливалася в межах 3,91...4,02 \% і білковомолочність - 3,22...3,32 \%, а у тварин групи “<8706” - 3,91...4,03 \% і 3,22...3,34 \% відповідно.

Достатньо інформативним показником молочної продуктивності є сумарна кількість молочного жиру і білка, яка у високопродуктивних тварин за першу лактацію становила 826,8 кг; другу - 869,0 кг; третю 836,7 кг. У корів групи “<8706” сумарна кількість молочного жиру і білка була нижчою і відповідно становила 558,7 кг; 728,0 кг; 727,5 кг.

Отже, якщо корови за першу лактацію виявили високий рівень продуктивності, то й у наступні лактації рівень іхнього надою буде збільшуватися за умови підтримання добробуту для забезпечення біологічних потреб тварин.

Особливості розвитку ознак високопродуктивних тварин можна оцінити, використовуючи показники мінливості, які наведено в таблиці 3. Встановлено, що варіабельність ознак молочної продуктивності за першу лактацію характеризується коефіцієнтами мінливості низького ступеня. Це пояснюється тим, що були сформовані групи піддослідних тварин за визначеними параметрами рівня надою. Для жирномолочності та білковомолочності характерними є показники мінливості низького ступеня.

Таблиця 3

Мінливість селекційних ознак у корів голштинської породи (дочірнє покоління)

\begin{tabular}{|c|c|c|c|c|c|c|c|c|c|c|c|}
\hline \multirow{2}{*}{$\begin{array}{c}\text { Група } \\
\text { корів за } \\
\text { рівнем } \\
\text { надою }\end{array}$} & \multirow{2}{*}{$\begin{array}{l}\text { Лакта- } \\
\text { ція }\end{array}$} & \multicolumn{2}{|c|}{ Надій } & \multicolumn{2}{|c|}{$\begin{array}{c}\text { Вміст жиру в } \\
\text { молоці }\end{array}$} & \multicolumn{2}{|c|}{$\begin{array}{c}\text { Кількість жиру в } \\
\text { молоці }\end{array}$} & \multicolumn{2}{|c|}{$\begin{array}{c}\text { Вміст білка в } \\
\text { молоці }\end{array}$} & \multicolumn{2}{|c|}{$\begin{array}{c}\text { Кількість білка } \\
\text { в молоці }\end{array}$} \\
\hline & & $\sigma$ & $C v, \%$ & $\sigma$ & $C v, \%$ & $\sigma$ & $C v, \%$ & $\sigma$ & $C v, \%$ & $\sigma$ & $C v, \%$ \\
\hline \multirow{3}{*}{$>10614$} & I & 647,07 & 5,7 & 0,155 & 3,9 & 31,63 & 7,0 & 0,070 & 2,1 & 22,61 & 6,1 \\
\hline & II & 1963,73 & 16,5 & 0,285 & 7,0 & 87,30 & 18,2 & 0,077 & 2,4 & 65,00 & 16,7 \\
\hline & III & 2030,27 & 17,8 & 0,289 & 7,1 & 77,76 & 16,8 & 0,088 & 2,7 & 64,41 & 17,3 \\
\hline \multirow{3}{*}{$<8706$} & I & 832,48 & 10,8 & 0,179 & 4,5 & 35,75 & 11,7 & 0,074 & 2,3 & 27,80 & 11,0 \\
\hline & II & 1539,03 & 15,4 & 0,267 & 6,7 & 65,11 & 16,3 & 0,072 & 2,2 & 49,40 & 15,0 \\
\hline & III & 1829,99 & 18,4 & 0,267 & 6,6 & 83,23 & 20,7 & 0,090 & 2,8 & 59,74 & 18,4 \\
\hline
\end{tabular}

У наступні лактації проявляється загальновідома тенденція високого ступеня мінливості молочності, оскільки дана ознака значною мірою проявляється під впливом середовищних факторів. Так, у високопродуктивних корів такі ознаки, як надій, кількість молочного жиру і білка за другу лактацію характеризуються коефіцієнтами варіабельності високого ступеня
$(C v=16,5 \%, C v=18,2 \%$ і $C v=16,7 \%)$. Про те, що рівень молочності змінюється в наступну, третю, лактацію свідчить мінливість ознак: надою, кількості молочного жиру і білка $(C v=17,8 \%, C v=16,8 \%$ i $C v=17,3 \%)$. Коефіцієнт мінливості надою становив 28,7 \%, кількості молочного жиру - 31,0 \% і кількості молочного білка - 29,8 \%. Це вказує на те, що в групі 
високопродуктивних тварин відбулося значне збільшення надою, але поряд 3 цим у окремих корів мінімальне його значення залишилося на рівні показника першої лактації.

Щодо корів групи “<8706”, то тенденція мінливості селекційних ознак майже подібна, проте виявлено деякі відмінності в показниках варіабельності, особливо за третю лактацію. Так, у низькопродуктивних корів такі ознаки, як надій, кількість молочного жиру i білка за другу лактацію характеризуються коефіцієнтами варіабельності високого ступеня $(C v=15,4 \%$, $C v=16,3 \%$ і $C v=15,0 \%)$. У результаті зміни рівня молочності за третю лактацію мінливість ознак підвищилася і характеризувалася коефіцієнтами мінливості високого ступеня: надою $-C v=18,4 \%$; кількості молочного жиру $-C v=20,7 \%$ та кількості молочного білка $-C v=18,4 \%$. Це пояснюється поступовою реалізацією продуктивності тварин голштинської породи у процесі їх господарського використання за інтенсивної технології виробництва молока.

Щодо корів, які були розподілені за рівнем надою в групу з середньою продуктивністю (“8707-10613”), то мінливість ознак за досліджувані лактації подібна до показників варіабельності тварин групи “<8706". Коефіцієнт мінливості надою за першу лактацію низького ступеня становив 6,0 \%, а 3 другої по четверту лактації перебував у межах 15,1..18,4 \%. Аналогічна тенденція спостерігається й за ознаками: кількість молочного жиру та білка в молоці, коефіцієнти мінливості яких за першу лактацію низького ступеня $(C v=7,8 \%$ і $C v=6,4 \%$ відповідно), а за другучетверту коливаються в межах $15,9 \ldots 19,7 \%$ i 15,9...19,7 \% відповідно.
Отже, мінливість селекційних ознак у корів різного рівня продуктивності характеризує їхній розвиток за період продукування у процесі господарського використання.

Для раннього прогнозування продуктивності тварин та їх відбору в селекції використовують ступінь повторюваності ознак. Якщо високий ступінь повторюваності, то це вказує на надійність відбору за попередніми оцінками. Якщо розвиток ознаки залежить від паратипових факторів, то ступінь їі повторюваності буде нижчим. Оскільки більшість селекційних ознак молочної худоби належать до кількісних ознак, які проявляються під впливом середовища, то для них характерна низька ступінь повторюваності.

Відомо, що рівень продуктивності корів $є$ основним для прибуткового молочного бізнесу, тож виникає необхідність оцінки продуктивних якостей корів 3 найбільшою іiі надійністю за першу лактацію. Для оцінки відносного впливу генотипу та середовища на мінливість ознак молочної продуктивності корів голштинської породи, розподілених на групи за величиною надою, визначали коефіцієнт повторюваності $\left(r_{w}\right)$ між послідовними вимірами ознаки.

Встановлено, що за першу, другу і третю лактації корови характеризувалися різним рівнем молочної продуктивності. Одні й ті ж ознаки, зокрема надій, кількість молочного жиру і кількість молочного білка за різні лактації відрізнялися між собою, що пояснюється віковими змінами у тварин. Проте між ними існує зв'язок, зумовлений спадковістю і паратиповими факторами. Для ознак молочної продуктивності за першу, другу i третю лактації високопродуктивних корів визначено коефіцієнти повторюваності, які наведено в таблиці 4.

\section{Таблиця 4}

Повторюваність ознак молочної продуктивності корів голштинської породи (дочірнє покоління)

\begin{tabular}{cccccccc}
\hline \multirow{2}{*}{$\begin{array}{c}\text { Група корів за } \\
\text { рівнем надою }\end{array}$} & \multirow{2}{*}{ Лактації } & \multicolumn{2}{c}{ Надій } & \multicolumn{3}{c}{ Кількість молочного жиру } & \multicolumn{2}{c}{ Кількість молочного білка } \\
\cline { 2 - 7 } & & $r_{w}$ & $p$ & $r_{w}$ & $p$ & $r_{w}$ & $p$ \\
\hline \multirow{3}{*}{$>10614$} & I-II & 0,099 & 0,200 & 0,106 & 0,169 & 0,073 & 0,342 \\
& I-III & 0,105 & 0,574 & 0,135 & 0,467 & 0,072 & 0,698 \\
& II-III & $-0,333$ & 0,067 & $-0,438$ & 0,014 & $-0,405$ & 0,024 \\
\hline \multirow{2}{*}{$<8706$} & I-II & 0,345 & 0,000 & 0,316 & 0,000 & 0,320 & 0,000 \\
& I-III & 0,190 & 0,195 & 0,150 & 0,307 & 0,158 & 0,284 \\
& II-III & 0,664 & 0,000 & 0,646 & 0,000 & 0,651 & 0,000 \\
\hline
\end{tabular}

На підставі даних повторюваності надою і кількості молочного жиру високопродуктивних корів (група “>10614”) встановили, що більші значення коефіцієнта характерні для лактацій I-III $\left(r_{w}=0,105 ; r_{w}=0,135\right)$. Дещо нижчі коефіцієнти повторюваності $\left(r_{w}=0,099 \mathrm{i}\right.$ $\left.r_{w}=0,106\right)$ цих ознак за I-II лактації вказує, що не завжди може повторюватися їх рівень за даними першої лактації. Наявність від’ємних значень коефіцієнтів повторюваності ознак молочної продуктивності для лактацій I-III ( $\left.r_{w}=-0,333 ; r_{w}=-0,438 ; r_{w}=-0,405 ;\right)$ свідчить не лише про невисоку повторюваність, а й вказують на можливість відсутності постійності цих ознак за різні періоди лактування корів. На нашу думку, це пояснюється збільшенням середовищної варіанси.
У результаті порівняльного аналізу встановлено, що низькопродуктивні тварин (група “<8706”) характеризувалися вищими коефіцієнтами повторюваності за I-II і II-III лактації $\left(r_{w}=0,345 ; r_{w}=0,316 ; r_{w}=0,320\right.$ і $r_{w}=0,664 ; r_{w}=0,646 ; r_{w}=0,651$ відповідно), тобто вони вирізняються вищою постійністю ознак молочної продуктивності за різні лактації. Це ще раз підтверджує, що відбір за даними першої лактації є результативним і якщо продуктивність нижча середнього по стаду, то не варто таку первістку залишати для подальшого використання.

Отже, більшою повторюваністю ознак молочної продуктивності характеризуються низькопродуктивні корови (група “<8706”), а тварини з високим рівнем продуктивності не вирізняються їхньою віковою пос- 
тійністю.

В селекції молочної худоби важливе значення має взаємозв'язок між господарсько корисними ознаками, особливо у високопродуктивних корів, оскільки це дозволяє прискорити отримання тварин 3 бажаним розвитком ознак. Встановлено, що кореляційна залежність між ознаками по-різному проявляється у високо- та низькопродуктивних корів (табл. 5).

\section{Таблиця 5}

Кореляція ознак молочної продуктивності корів голштинської породи (дочірнє покоління)

\begin{tabular}{|c|c|c|c|c|c|c|}
\hline \multirow{2}{*}{$\begin{array}{c}\text { Група корів } \\
\text { за рівнем } \\
\text { надою } \\
\end{array}$} & \multirow[b]{2}{*}{ Параметр } & \multicolumn{5}{|c|}{ Ознаки, що корелюють } \\
\hline & & $\begin{array}{c}\text { надій } \times \text { вміст } \\
\text { жиру в молоці }\end{array}$ & $\begin{array}{l}\text { надій } \times \text { кількість } \\
\text { молочного жиру }\end{array}$ & $\begin{array}{l}\text { надій } \times \text { вміст } \\
\text { білка в молоці }\end{array}$ & $\begin{array}{l}\text { надій } \times \text { кількість } \\
\text { молочного білка }\end{array}$ & $\begin{array}{c}\text { вміст жиру × вміст } \\
\text { білка в молоці } \\
\end{array}$ \\
\hline \multicolumn{7}{|c|}{ I лактація } \\
\hline \multirow{2}{*}{$>10614$} & $r$ & 0,023 & 0,826 & $-0,007$ & 0,934 & 0,434 \\
\hline & $p$ & 0,705 & 0,001 & 0,901 & 0,000 & 0,000 \\
\hline \multirow{2}{*}{$<8706$} & $r$ & 0,007 & 0,921 & 0,012 & 0,979 & 0,419 \\
\hline & $p$ & 0,904 & 0,001 & 0,841 & 0,000 & 0,000 \\
\hline \multicolumn{7}{|c|}{ II лактація } \\
\hline \multirow{2}{*}{$>10614$} & $r$ & 0,015 & 0,918 & $-0,008$ & 0,989 & 0,541 \\
\hline & $p$ & 0,838 & 0,000 & 0,918 & 0,000 & 0,000 \\
\hline \multirow{2}{*}{$<8706$} & $r$ & $-0,091$ & 0,905 & $-0,251$ & 0,990 & 0,427 \\
\hline & $p$ & 0,272 & 0,000 & 0,002 & 0,000 & 0,000 \\
\hline \multicolumn{7}{|c|}{ III лактація } \\
\hline \multirow{2}{*}{$>10614$} & $r$ & $-0,423$ & 0,919 & $-0,332$ & 0,986 & 0,594 \\
\hline & $p$ & 0,018 & 0,000 & 0,068 & 0,000 & 0,000 \\
\hline \multirow{2}{*}{$<8706$} & $r$ & 0,201 & 0,948 & $-0,149$ & 0,990 & 0,296 \\
\hline & $p$ & 0,169 & 0,000 & 0,311 & 0,000 & 0,041 \\
\hline
\end{tabular}

Загальновідомо, що між надоєм і вмістом жиру в молоці існує від'ємна кореляція низького і середнього ступеня. За високого рівня надою у корів групи ">10614" така залежність 3'явилася в третю лактацію. Якщо в першу і другу лактації коефіцієнт кореляції між надоєм і вмістом жиру в молоці становив 0,023 0,015 , то за третю лактацію - -0,423. Це свідчить про те, що саме збільшення величини надою спричиняє виникнення від'ємної кореляційної залежності. Поряд 3 цим виявлено від'ємну кореляцію низького і середнього ступеня між надоєм і вмістом білка в молоці за першу, другу і третю лактації $(r=-0,007 ; r=-0,008$; $r=-0,332$ відповідно). Також знайшла підтвердження закономірність існування додатного зв'язку високого ступеня між надоєм і кількістю молочного жиру та білка $(r=0,826 \ldots 0,919, P<0,001$ і $r=0,934 \ldots 0,989$, $P<0,001)$, додатного зв'язку середнього ступеня між вмістом жиру і білка в молоці $(r=0,434 \ldots 0,594$, $P<0,001)$.

Кореляційна залежність між ознаками у низькопродуктивних тварин (група “<8706”) має деякі відмінності, зокрема між надоєм і вмістом жиру в молоці за третю лактацію встановлено додатну кореляцію низького ступеня $(r=0,201)$. За меншого рівня надою від'ємна кореляція між надоєм і вмістом жиру в молоці не проявляється. Проте у корів групи “<8706" виявлено від'ємну кореляцію середнього і низького ступеня між надоєм і вмістом білка в молоці за другу $(r=-0,251, P<0,01)$ і третю $(r=-0,149)$ лактації.

Аналогічно встановлено існування додатної кореляції високого ступеня між надоєм і кількістю молочного жиру та білка за першу, другу і третю лактації ( $r=0,921, P<0,001 ; r=0,905, P<0,001 ; r=0,948$, $P<0,001$ i $r=0,979, P<0,001 ; r=0,990, P<0,001$; $r=0,990, P<0,001)$.

Таким чином, доведено існування від'ємної коре- ляції між надоєм та вмістом жиру в молоці за високого рівня продуктивності тварин, а між надоєм та вмістом білка в молоці як за високого, так і низького рівня продуктивності корів.

\section{Висновки}

Дослідженнями встановлено, що високий рівень продуктивності корів за першу лактацію свідчить про збільшення надою і в наступні лактації, але інтенсивне продукування зумовлює швидше вибуття тварин зі стада. У високопродуктивних корів такі ознаки, як надій, кількість молочного жиру і білка за другу i третю лактації характеризувалися коефіцієнтами варіабельності високого ступеня $(C v=16,5 \ldots 18,2 \%)$. У низькопродуктивних корів спостерігалася подібна тенденція мінливості селекційних ознак.

Встановлено, що високопродуктивні корови характеризувалися нижчими коефіцієнтами повторюваності, а низькопродуктивні тварин (група “<8706”) мали вищі коефіцієнтами повторюваності за I-II і II-III лактації $\left(r_{w}=0,316 \ldots 0,664\right)$, тобто вони вирізнялися більшою постійністю ознак молочної продуктивності за різних лактацій.

Доведено існування від'ємної кореляції між надоєм та вмістом жиру в молоці за високого рівня продуктивності тварин $(r=-0,423)$, а між надоєм та вмістом білка в молоці як за високого, так і низького рівня продуктивності корів.

Перспективи подальших досліджень. Передбачається у подальшому дослідити ознаки відтворювальної здатності та прояв поєднаних ознак високопродуктивних корів голштинської породи. 


\section{References}

Babik, N. P. (2018). Produktyvne dovholittia koriv molochnykh porid zalezhno vid tryvalosti yikh pershoho servis-periodu. Naukovyi visnyk Lvivskoho natsionalnoho universytetu veterynarnoi medytsyny ta biotekhnolohii im. S. Z. Hzhytskoho, 20(84), 9-15. doi: $10.15421 /$ nvlvet8402 (in Ukrainian).

Babik, N. P., Fedorovych, Ye. I., \& Fedorovych, V. V. (2017). Vplyv zhyvoi masy koriv holshtynskoi porody $\mathrm{u}$ period vyroshchuvannia na tryvalist ta efektyvnist yikh hospodarskoho vykorystannia. Naukovyi visnyk Lvivskoho natsionalnoho universytetu veterynarnoi medytsyny ta biotekhnolohii im. S. Z. Hzhytskoho, 19(74), 71-75. doi: 10.15421/nvlvet7416 (in Ukrainian).

Ferents, L. V. (2017). Vidtvoriuvalna zdatnist ta molochna produktyvnist koriv zalezhno vid pleminnoi tsin-nosti yikh batkiv. Naukovyi visnyk Lvivskoho natsionalnoho universytetu veterynarnoi medytsyny ta biotekh-nolohii im. S. Z. Hzhytskoho, 19(74), 48-51. doi: 10.15421/nvlvet7411 (in Ukrainian).

Khmelnychyi, L. M., \& Loboda, V. P. (2015). Vplyv populiatsiino-henetychnykh ta paratypovykh chynnykiv na oznaky molochnoi produktyvnosti koriv ukrainskoi chervono-riaboi molochnoi porody. Visnyk Sumskoho natsionalnoho ahrarnoho universytetu, 2(27), 27-31. URL: http://nbuv.gov.ua/UJRN/Vsna_tvar_2015_2_5 (in Ukrainian).

Koropets, L. A., Boiko, O. V., \& Kutova, V. V. (2016). Molochna produktyvnist koriv holshtynskoi porody za-lezhno vid liniinoi nalezhnosti. Tvarynnytstvo ta tekhnolohii kharchovykh produktiv, 250, 75-80 (in Ukrainian).

Kramarenko, S. S., Kuzmichova, N. I., \& Kramarenko, O. S. (2018). Analiz vzaiemodii "henotyp kh seredovyshche" na molochnu produktyvnist koriv. Naukovyi visnyk Lvivskoho natsionalnoho universytetu veterynarnoi medy-tsyny ta biotekhnolohii im. S. Z. Hzhytskoho, 20(89), 27-33. doi: 10.32718/nvlvet8905 (in Ukrainian).

Kramarenko, S. S., Kuzmichova, N. I., \& Kramarenko, O. S. (2019). Vykorystannia bahatovymirnykh metodiv analizu vnutrishnoporodnoi minlyvosti vmistu zhyru v molotsi molochnoi khudoby. Naukovyi visnyk
Lvivskoho natsiona-lnoho universytetu veterynarnoi medytsyny ta biotekhnolohii im. S. Z. Hzhytskoho, 21(91), 3-9. doi: 10.32718/nvlvet9101 (in Ukrainian).

Kramarenko, S. S., Luhovyi, S. I., Lykhach, A. V., \& Kramarenko, O. S. (2019). Analiz biometrychnykh danykh u rozve-denni ta selektsii tvaryn. Mykolaiv, MNAU (in Ukrainian).

Livinskyi, A. I. (2014). Suchasni pytannia vidtvorennia molochnoho stada. Tvarynnytstvo ta tekhnolohii kharcho-vykh produktiv, 202, 339-344 (in Ukrainian).

Morozova, N. I., Musaev, F. A., \& Ivanova, L. V. (2012). Molochnaja produktivnost' golshtinskih korov ven-gerskoj selekcii. Fundamental'nye issledovanija, 6(2), 405-408. URL: $\quad$ https://cyberleninka.ru/article/n/molochnayaproduktivnost-korov-golshtinskoy-porody-razlichnoyselektsii (in Russian).

Pidpala, T. V., \& Matashniuk, Yu. S. (2017). Otsinka potokovo-tsekhovoi systemy vyrobnytstva moloka. Visnyk ah-rarnoi nauky Prychornomoria, 2, 136-144. doi: 10.31521/2313-092X (in Ukrainian).

Pidpala, T. V., \& Matashniuk, Yu. S. (2019). Vysokoproduktyvni korovy holshtynskoi porody $\mathrm{v}$ umovakh intensyv-noi tekhnolohii. Visnyk ahrarnoi nauky Prychornomoria, 2(102), 82-88. doi: 10.31521/2313092X/2019-2(102)-6 (in Ukrainian).

Pidpala, T. V., Kramarenko, O. S., \& Zaitsev, Ye. M. (2018). Vykorystannia entropiinoho analizu dlia otsinky rozvy-tku oznak molochnoi khudoby holshtynskoi porody. Naukovyi visnyk Lvivskoho natsionalnoho universytetu veterynarnoi medytsyny ta biotekhnolohii im. S. Z. Hzhytskoho, 20(84), 3-8. doi: 10.15421/nvlvet8401 (in Ukrainian).

Pidpala, T. V., Voinalovych, S. A., Nazarenko, V. H., Herasymenko, V. V., Strikha, L. O., \& Tskhvitava, O. K. (2012). Selektsiia molochnoi khudoby i svynei: navch. posibnyk. Mykolaiv: MNAU (in Ukrainian).

Pidpala, T. V., Zaitsev, Ye. M., \& Pravda, A. O. (2019). Rezultaty vykorystannia buhaiv-plidnykiv holshtynskoi porody pry stvorenni vysokoproduktyvnoho stada. Visnyk Poltavskoi derzhavnoi ahrarnoi akademii, 1, 169-180. doi: 10.31210/visnyk2019.01.19 (in Ukrainian).

Shkurko, T. (2014). Produktyvne vykorystannia koriv. Tvarynnytstvo Ukrainy, 7, 5-9 (in Ukrainian). 